\title{
Metody, strategie, wyniki
}

Media są w modzie. Media same w sobie są modą. Dla badaczy wielu bardzo rozmaitych dziedzin obszar mediów stał się przestrzenią eksploracji i poznawczych doświadczeń, płaszczyzną odniesień, porównań, bezkresem dowodów potwierdzających, wydawać by się mogło, wszelkie teorie. Media są dzisiaj, co tylko czasami i dość nieśmiało pojawia się w metarefleksji badawczej, hurtownią materiału egzemplifikacyjnego, rezerwuarem treści wszelkich, jakie tylko można sobie wyobrazić, chcieć, których się potrzebuje, by wykazać i udowodnić, wesprzeć i podbudować sformułowane tezy. To bardzo atrakcyjne, ale jednocześnie niezwykle groźne dla badaczy mediów.

W wielu wypadkach przyglądając się temu, jak próbuje się prowadzić prace badawcze obejmujące materiał medialny, dochodzi się do niepokojącego wniosku, że kompetencja może się tu sprowadzić niemal wyłącznie do sprawnego i przyswojonego repertuaru działań o charakterze wyszukiwawczym. Duże bazy danych i zawarte w nich niepoliczalne niemal treści pozwalają zdobyć materiał do wszelkich możliwych analiz. On jest na wyciągnięcie ręki, wystarczy opanować operowanie słowami kluczowymi w wyszukiwarkach.

Takie wrażenie można mieć. Znajdzie się też wcale liczne przykłady prac, które w zasadzie ograniczają się do zebrania, uporządkowania, często pobieżnego, zgromadzonego materiału ilustracyjnego, a następnie jego zreferowania. Staram się w kolejnych wprowadzeniach do poszczególnych tomów czasopisma wskazywać na pewne zagrożenia i ważne zjawiska w przestrzeni badawczej medioznawstwa. Zwrócenie uwagi na ten obszar problemów uważam za istotne. Wciąż bowiem brakuje ugruntowanych, upowszechnionych i spragmatyzowanych zestawów przedyskutowanych i akceptowalnych metodologii, a te, które znamy i z których w większości się korzysta, są łączone, modyfikowane lub wykorzystywane fragmentarycznie. Tak przynajmniej 
bywa, co jest zapewne wynikiem wciąż jeszcze nie do końca wykrystalizowanego i zwartego środowiska badaczy mediów z jednej strony, a z drugiej wspomnianego na początku niezwykle atrakcyjnego mediatyzowania nie tylko wszelkich przestrzeni naszego życia publicznego i prywatnego, ale i - tak to ujmę - mediatyzowania materiału badawczego licznych dyscyplin. Ponieważ jesteśmy w czasie istotnych zmian organizacyjnych i formalnych polskiej nauki, nie można nie udokumentować tego, że na swoistą niepodległość wybija się dyscyplina nauk o mediach i komunikacji społecznej. Zakres jej jest szeroki, wpisuje się w nią bowiem dotychczas istniejąca bibliologia i informatologia z jej zestawem narzędzi, ugruntowanym obszarem zainteresowań badawczych i historycznie ukształtowanym środowiskiem badaczy. Inspirujące będzie przyglądanie się, jakie ten mariaż ostatecznie przyniesie owoce.

W tym numerze „Dziennikarstwa i Mediów” prezentujemy tradycyjne teksty o charakterze steoretyzowanym, o pewnych ambicjach metodologicznych, oraz teksty praktyczne, przynoszące wyniki badań i analiz mediów: profesji dziennikarskiej, gatunków dziennikarskich, wizerunku, konstruktów komunikacyjnych, reklamy, badań z zakresu brandingu i marki. Kontekst metodologiczny tym razem odzwierciedla trzy nurty zainteresowań i badań naszego środowiska medioznawczego - znajdziemy tu zarówno refleksje o charakterze dziennikarskim, jak i językoznawczym oraz związanym z kształtowaniem wizerunku. W części praktycznej publikujemy teksty odnoszące się do zagadnień wizerunkowych, gatunków mowy i typów aktywności komunikacyjnej w mediach społecznościowych, teksty odnoszące się do marketingu politycznego i zarządzania wizerunkiem w mediach. Nie brakuje także poznawczych wycieczek w kierunku praktyki pracy dziennikarskiej: analiz warsztatu dziennikarstwa sportowego oraz tych prowadzonych w kontekście porównawczym warsztatu reporterskiego.

$\mathrm{Na}$ łamach pojawiają się stali autorzy i debiutanci, absolwenci kierunków prowadzonych w Instytucie Dziennikarstwa i Komunikacji Społecznej Uniwersytetu Wrocławskiego: dziennikarstwa i komunikacji społecznej oraz komunikacji wizerunkowej. Wśród autorów spotkamy reprezentantów nie tylko uniwersyteckiego medioznawstwa, ale i badaczy z innych ośrodków, w tym z zaprzyjaźnionego Uniwersytetu Karola w Pradze. 